\title{
EVALUATION OF ANTIARTHRITIC POTENTIAL AND PHYTOCHEMICAL ANALYSIS OF DIFFERENT FRACTIONS OF SELECTED MEDICINAL PLANTS
}

\author{
Nabarun Mukhopadhyay ${ }^{1}$, Sampath. V $^{2}$, Sameer Pai ${ }^{2}$, U. V. Babu ${ }^{2}$ \\ and Richard Lobo ${ }^{1, \bowtie}$ \\ ${ }^{1}$ Department of Pharmacognosy, Manipal College of Pharmaceutical Sciences, Manipal \\ Academy of Higher Education, Manipal- 576104, Karnataka, India. \\ ${ }^{2}$ R\&D center, The Himalaya Drug Company, Makali, Bangalore- 562162, Karnataka. \\ ${ }^{\square}$ Corresponding Author: richardlobo73@gmail.com
}

\begin{abstract}
Arthritis is a chronic inflammatory condition that is a major disability throughout the world. For so many years there are several therapies used for the treatment but they have many disadvantages like side effects, poor bioavailability, high cost etc. So, researches are going on for the development of alternative effective therapy for arthritis. The current study explores anti-arthritic activity (by targeting pro-inflammatory cytokines like IL-6) and phytochemical analysis of different fractions of Capsicum annum, Boswellia serrata and Lawsonia inermis. In this study overall seven fractions were prepared with the help of fractionation. They were coded as $\mathrm{CO}$, COHF, COMF, BPS, HMEP, HMAP and HAMF. The anti-inflammatory activity of the fractions was evaluated by using an in-vitro IL-6 and TNF-a ELISA study. The non-toxic concentration of the study samples was determined by MTT assay. High-PerformanceThin-Layer Chromatography was used for qualitative analysis of phytoconstituents present in the fractions. Liquid Chromatography-Mass Spectroscopy was used for the identification of phytoconstituents present in the fractions of COMF, BPS and HMEP. HPTLC analysis revealed the presence of capsaicin, galactose, arabinose, luteolin, $\beta$-sitosterol, LCMS analysis showed the presence of capsaicin, luteolin, lalioside and arabinose.
\end{abstract}

Keywords: Arthritis, Inflammation, Fractionation, In-vitro study, HPTLC,Tumour necrosis

RASĀYAN J. Chem., Vol. 14, No.1, 2021

\section{INTRODUCTION}

Arthritis is a combinatorial word originated by the mixing of Latin word "Arthron" which signifies joint and Greek word "Itis" inflammation. It is an incessant, incendiary and systemic autoimmune disease that principally affects the joints of the human body. There are several forms of arthritis are there, they are; Autoimmune (Rheumatoid arthritis (RA), Reiter syndrome etc.), Degenerative like Osteoarthritis (OA), Crystal deposition (Gout) etc. Out of those RA and OA are most commonly affected the human body. The initial symptoms are weakness, musculoskeletal agony and stiffness and it affects human joints after some months. The small joints are affected initially but later bigger joints are likewise influenced, become swollen, warm and agonizing. ${ }^{1}$

The prevalence of arthritis is increased worldwide nowadays. Some facts proved that it becomes a major disease and many people are affected by it. From 2013 to 2015 in the United States ${ }^{2}$, individuals matured between 18 to 44 years, $7.1 \%$ reported having arthritis. In general, $26 \%$ of women and 19 .of $1 \%$ of men were accounted for to have arthritic thee the US from 2013205. ${ }^{2}$ In,India it is seen that osteoarthritis is prevalent among all forms of arthritis. ${ }^{3}$

The exact pathophysiology of this disease is yet to be known but hypotheses said that several free radicals name nitrous oxide and superoxide radicals are generated as byproducts due to cellular metabolism. Interleukins and Tumour necrosis factor (TNF- $\alpha$ ) which are produced from T-cells may be induced by the release of those free radicals which influences the growth factors production, tissue destruction and inflammation may happen due to the cytokines and adhesive molecules on the immune. ${ }^{4}$ The pathological changes seen in arthritic patients are synovial membrane hyperplasia, cartilage erosion and articular destruction are seen due to the inflammatory cells infiltration and neovascularization. ${ }^{5}$

The prolonged use of the conventional treatment against arthritis leads to adverse reactions, including severe infections. So the research is going on for the development of relatively effective alternatives 
but less expensive therapies with minimal or no side effects for treating arthritis. ${ }^{6}$ Here natural plant products become vital and promising resources for developing new therapeutically active pharmaceutical products for the treatment of arthritis. From the knowledge and detailed survey of the medicinal plants, the discovery of new drugs might be possible which are therapeutically effective and also cheaper. ${ }^{7}$

In this study, three medicinal plants were taken as Capsicum annum, Boswellia serrata and Lawsonia inermis.

Capsaicinoids are the major active constituent of $C$. annum, composes of capsaicin, dihydrocapsaicin, nordihydrocapsaicin, homocapsaicin, homodihydrocapsaicin and nonivamide. ${ }^{8}$ The capsaicin is currently used for treating osteoarthritis. ${ }^{9}$ It has a membrane-stabilizing property by the interference of activation of phospholipase A2. ${ }^{10}$

Boswellic acids (BAs) are major pharmacologically active constituents of B. serrata. ${ }^{11}$ There are six major BAs were reported, they are $\alpha$ and $\beta$-Boswellic Acids (BA, 10-21\%), Acetylated $\alpha$ and $\beta$ Boswellic Acids (ABA, 0.05-6\%), 11-keto- $\beta$-Boswellic acid (KBA, 2.5- 7.5\%) and 3-O-acetyl-11keto- $\beta$-Boswellic acid (AKBA, $0.1-3 \%$ ). ${ }^{12}$ It also contains polysaccharides which is the combination of arabinose with a minute quantity of xylose and galactose. ${ }^{13}$ It is seen that the population of leucocytes is reduced by the oral administration of BAs, it also inhibits polymorphonuclear leukocytes migration in vitro and electrophoretic pattern of synovial fluid protein was also changed in bovine serum albumin (BSA) induced arthritis. ${ }^{14}$

The plant L. inermis is widely found in India, contains a natural dye Lawsone ${ }^{15}$ Other important compounds present in the leaves are flavonoids (luteolin, apigenin etc.), Coumarins (esculetin, fraxetin, scopletin) and Steroids ( $\beta$-sitosterol). ${ }^{16}$ Two compounds named Isoplumbagin and lawsaritol from the stem bark and root of $L$. inermis showed anti-inflammatory effect against Carrageenan induced paw oedema model. At $100 \mathrm{mg} / \mathrm{kg}$ oral dose isoplumbagin and lawsaritol showed 61 and $60 \%$ inhibition along with $40 \%$ inhibition showed by phenylbutazoneinin comparison with controls. Isoplumbagin showed potent anti-inflammatory activity. ${ }^{17}$ Butanol and chloroform fractions showed more potent anti-inflammatory, pain-relieving and antipyretic effects than aqueous fraction of crude ethanol extract of $L$. inermis in a portion subordinate way. ${ }^{18}$

\section{Material and Methods}

\section{EXPERIMENTAL}

\section{Collection and Authentication of Plant Materials}

All the herbs were collected and authenticated by the Pharmacognosy department, The Himalaya Drug Company, Bangalore, Karnataka, India.

\section{General Procedure}

Extraction and Fractionation of Plant Materials

Extraction and Fractionation of Capsicum oleo Resin from $C$. annum

Dried $5 \mathrm{~kg}$ of Red chilli was coarsely powdered and refluxed with $15 \mathrm{~L}$ acetone at $55^{\circ} \mathrm{C}$ for $1 \mathrm{~h}$, keep it for 30 minutes and filter. The extraction process was repeated twice under the same conditions. All three filtrates were concentrated in a vacuum rota evaporator. About $200 \mathrm{~g}$ of oleo resin was obtained and decoded as $\mathrm{CO}$ (capsicum oleo resin) for further study. The fractionation of $\mathrm{CO}$ was done by using different solvents.

Oleo resin of about $200 \mathrm{~g}$ was fractioned with $4 \mathrm{~L}$ hexane. The hexane fraction was concentrated under vacuum and decoded as COHF (hexane fraction). Hexane insoluble portion was dissolved in $200 \mathrm{ml}$ chloroform and partitioned with $2 \mathrm{~L}$ of demineralized water. Dried the organic layer separately and discarded the aqueous layer. The organic layer was redissolved with $400 \mathrm{ml}$ of methanol and allowed to stand for overnight. The methanolic layer was gently decanted and partitioned with $10 \mathrm{~L}$ hexane. The methanolic layer was collected and concentrated in Rotavapour Buchi and decoded as COMF (methanol fraction).

\section{Extraction of Boswellia and Estimation of Polysaccharides}

About $5 \mathrm{~kg}$ of Boswellia oleo gum resin was taken to which water was added and heated at $90-100^{\circ} \mathrm{C}$ under stirring for $3 \mathrm{~h}$. Extraction was repeated thrice under the same conditions and the extracts were filtered through 100 mesh muslin cloth. All filtrates were combined and concentrated using a water bath. A dried extract of about $600 \mathrm{~g}$ was obtained. 
About $10 \mathrm{~g}$ of the aqueous extract of $B$. serrata was taken and $50 \mathrm{ml}$ of methanol was added, refluxed at $70^{\circ} \mathrm{C}$ for 25 minutes. The procedure was repeated thrice and discarded the filtrate. The marc obtained was subjected to hydrolysis reaction. Thereafter $50 \mathrm{ml}$ dilute hydrochloric acid was added and refluxed at $100{ }^{\circ} \mathrm{C}$ for $3 \mathrm{~h}$, the mixture was allowed to stand for 20 minutes and filtered, $\mathrm{pH}$ was adjusted between 6.5-7 using ammonia and the filtrate was evaporated up to $20 \mathrm{ml}$. Then $200 \mathrm{ml}$ of ethanol was added under magnetic stirrer and allowed it to stand for $1 \mathrm{~h}$. The mother liquor was collected and concentrated under rota evaporator and decoded as BPS (Boswellia polysaccharides).

\section{Extraction of L. inermis (Henna Leaves)}

The henna powder of about $268 \mathrm{~g}$ was extracted with methanol. The process was repeated twice. The residue obtained was treated with water at $94{ }^{\circ} \mathrm{C}$ for $3 \mathrm{~h}$. The aqueous extract was filtered and concentrated on the water bath till it reaches TS (total solid content) $40 \%$. About $110 \mathrm{ml}$ of final concentrated liquid was obtained. Both methanolic and aqueous extracts were coded as HM (henna methanolic extract) and HA (henna aqueous extract) taken for further fractionation process.

\section{Fractionation of Aqueous and Methanolic Extract}

The aqueous extract was treated with $300 \mathrm{ml}$ methanol under continuous stirring, it was filtered, washed the precipitate with methanol followed by $100 \mathrm{ml}$ acetone. The precipitate was dried at $65{ }^{\circ} \mathrm{C}$ which was taken as a study sample and de coded as HAMF (methanolic fraction). The methanolic extract of henna was taken to which $1 \mathrm{~L}$ of hexane was added. The hexane insoluble portion was separated and redissolved in water. Then it was partitioned with $500 \mathrm{ml}$ hexane. The aqueous layer was separated and partitioned with ethyl acetate. Ethyl acetate was concentrated separately. It was decoded as HMEP (ethyl acetate partition) and HMAP (aqueous partition).

\section{In-vitro Anti-inflammatory Study of prepared Fractions}

IL-6 ELISA and TNF-œ ELISA studies were used to determine the anti-inflammatory activity of the prepared fractions.

\section{Cytotoxicity Study by MTT Assay ${ }^{19}$}

The THP-1 (Human peripheral blood monocytes) cells were grown in 96 well plates in RPMI 1640 with $2 \%$ FBS and incubated for the assay. The initial stock solution of the test product $(10 \mathrm{mg} / \mathrm{ml})$ was prepared and further diluted with 1:10 ratio by dissolving in RPMI 1640 medium with 2\% FBS and from that sample, subsequent dilutions were made to obtain the concentration of $1000,500,250,125$, $62.5,31.25$ and $15.625 \mu \mathrm{g} / \mathrm{ml}$. The dilutions $(100 \mu \mathrm{l} /$ well) were added to the THP-1 cells and incubation was done at $37^{\circ} \mathrm{C}$ with $5 \% \mathrm{co}_{2}$. Cell control was also maintained. After $24 \mathrm{hrs}$ incubation, the cell viability was determined by MTT assay. In MTT assay, $10 \mu 1$ of MTT $(5 \mathrm{mg} / \mathrm{ml})$ solution was added into each well and incubated for 4 hours at $37^{\circ} \mathrm{C}$. The cell supernatant was discarded and the cell bound dye was extracted by adding $100 \mu$ of dimethyl sulfoxide (DMSO) into each well and the measurement of absorbance was done at $540 \mathrm{~nm}$. The \% cytotoxicity was determined from absorbance estimations of treated and control groups. The $\mathrm{CTC}_{50}$ values for the sample were determined.

\section{IL-6 ELISA (Enzyme-linked Immunosorbent Assay) Study ${ }^{19}$}

The study was carried out in THP-1 cells. To activate the secretion of IL-6 cytokines the cells were exposed to $1 \mu \mathrm{g} / \mathrm{mL}$ of lipopolysaccharide (LPS) and co-treated with prepared test samples. Incubation was done for $24 \mathrm{~h}$ at $37^{\circ} \mathrm{C}$ and the cell supernatant was separated by centrifugation. The content of IL-6 was quantitatively estimated according to the assay procedure provided in KitKrishgen Biosystem ELISA kit catalog: KB1068. Dexamethazone was used as a reference drug. All incubation steps were performed at room temperature. A microplate reader was used to determining the optical density at $450 \mathrm{~nm}$.

\section{TNF-œ ELISA Study ${ }^{19}$}

The study was carried out in THP-1 cells. For the activation of the secretion of TNF-œ cytokines the cells were exposed to $1 \mu \mathrm{g} / \mathrm{ml}$ of lipopolysaccharide (LPS). The cells were co-treated with prepared test samples and incubated for $24 \mathrm{~h}$ at $37^{\circ} \mathrm{C}$. then, the cell supernatant was separated by centrifugation. TNF-œ levels were estimated by ELISA performed according to the assay procedure provided by the manufacturer (Kit- Krishgen Biosystem ELISA kit catalog: TA0119). Dexamethazone was used as a MEDICINAL PLANTS 
standard drug in this study. All incubation steps were performed at room temperature. Microplate reader was used to determining the optical density at $450 \mathrm{~nm}$.

From the anti-inflammatory studies, it was found that six fractions showed good anti-inflammatory activity compared with Dexamethazone. Further HPTLC and LCMS analysis was done for the identification of phytoconstituents in the selected fractions.

\section{HPTLC Analysis of Selected Fractions}

HPTLC analysis of six fractions named CO, COHF, COMF, BPS, HMEP and HMAP was carried out.

Table-1: Mobile Phases used for the Fractions

\begin{tabular}{l|l|l}
\hline Fractions & Mobile Phases Used & Visualizing Agents Used \\
\hline $\begin{array}{l}\text { CO, COHF and } \\
\text { COMF }\end{array}$ & Toluene: Chloroform: Acetone (5.5: 2.6: 1.9) & Vanillin sulphuric acid \\
\hline HPS & n-propanol: Water $(8.5: 1.5)$ & Vanillin sulphuric acid \\
\hline $\begin{array}{l}\text { Toluene: Ethyl acetate: Formic acid }(10: 9: 1) \text { (for luteolin) } \\
\text { (for } \beta \text {-sitosterol) } \\
\text { Chloroform: Methanol }(9: 1) \text { (for unknown terpenoid) }\end{array}$ & $\begin{array}{l}\text { Vanillin sulphuric acid and } \\
\text { Alcl3 }\end{array}$ \\
\hline HMAP & Chloroform: Methanol: Water $(6: 3.5: 0.5)$ & Vanillin sulphuric acid \\
\hline
\end{tabular}

\section{LCMS Estimation of COMF, HMEP and BPS}

The LCMS estimation was carried out based on the following conditions:

\begin{tabular}{ll}
\hline Parameter & Optimization values \\
\hline Ion source & Electron spray ionization (ESI turbo spray) \\
\hline Declustering potential & $20 \mathrm{~V}$ \\
\hline Focusing table (FP) & $400 \mathrm{~V}$ \\
\hline Entrance potential (EP) & $10 \mathrm{~V}$ \\
\hline Curtain gas (CUR) & $20 \mathrm{psi}$ \\
\hline Ion spray voltage (IS) & $5500 \mathrm{~V}$ \\
\hline Temperature & $0^{0} \mathrm{C}$ \\
\hline Nebulizer gas (GS1) & $30 \mathrm{psi}$ \\
\hline Heater gas (GS2) & $40 \mathrm{psi}$
\end{tabular}

\section{RESULTS AND DISCUSSION}

In-vitro anti-inflammatory Studies of prepared Study Samples

Cytotoxicity Study by MTT assay

Table-2: Quantitative Determination of Non-toxic Concentration of prepared Fractions on THP-1 Cells

\begin{tabular}{|c|c|c|c|c|c|}
\hline S.No. & $\begin{array}{c}\text { Name of the } \\
\text { Fraction }\end{array}$ & $\begin{array}{c}\text { CTC }_{50} \text { Values } \\
(\mu \mathrm{g} / \mathrm{ml})\end{array}$ & Induction & $\begin{array}{c}\text { Concentration of the } \\
\text { Test Samples }\end{array}$ & Solubility \\
\hline \multirow[t]{2}{*}{1.} & \multirow[t]{2}{*}{$\mathrm{CO}$} & \multirow[t]{2}{*}{209.74} & \multirow[t]{2}{*}{$1 \mu \mathrm{g}$ LPS } & $200 \mu \mathrm{g} / \mathrm{ml}$ & \multirow[t]{2}{*}{ DMSO } \\
\hline & & & & $100 \mu \mathrm{g} / \mathrm{ml}$ & \\
\hline \multirow[t]{2}{*}{2.} & \multirow[t]{2}{*}{$\mathrm{COHF}$} & \multirow[t]{2}{*}{415.34} & \multirow[t]{2}{*}{$1 \mu \mathrm{g}$ LPS } & $200 \mu \mathrm{g} / \mathrm{ml}$ & \multirow[t]{2}{*}{ DMSO } \\
\hline & & & & $100 \mu \mathrm{g} / \mathrm{ml}$ & \\
\hline \multirow[t]{2}{*}{3.} & \multirow[t]{2}{*}{ COMF } & \multirow[t]{2}{*}{96.15} & \multirow[t]{2}{*}{$1 \mu \mathrm{g}$ LPS } & $100 \mu \mathrm{g} / \mathrm{ml}$ & \multirow[t]{2}{*}{ DMSO } \\
\hline & & & & $50 \mu \mathrm{g} / \mathrm{ml}$ & \\
\hline \multirow[t]{2}{*}{4.} & \multirow[t]{2}{*}{ BPS } & \multirow[t]{2}{*}{829.68} & \multirow[t]{2}{*}{$1 \mu \mathrm{g}$ LPS } & $500 \mu \mathrm{g} / \mathrm{ml}$ & \multirow[t]{2}{*}{ Aqueous } \\
\hline & & & & $250 \mu \mathrm{g} / \mathrm{ml}$ & \\
\hline \multirow[t]{2}{*}{5.} & \multirow[t]{2}{*}{ HMEP } & \multirow[t]{2}{*}{250.94} & \multirow[t]{2}{*}{$1 \mu \mathrm{g}$ LPS } & $200 \mu \mathrm{g} / \mathrm{ml}$ & \multirow[t]{2}{*}{ DMSO } \\
\hline & & & & $100 \mu \mathrm{g} / \mathrm{ml}$ & \\
\hline \multirow[t]{2}{*}{6.} & \multirow[t]{2}{*}{ HMAP } & \multirow[t]{2}{*}{$>1000$} & \multirow[t]{2}{*}{$1 \mu \mathrm{g}$ LPS } & $500 \mu \mathrm{g} / \mathrm{ml}$ & \multirow[t]{2}{*}{ DMSO } \\
\hline & & & & $250 \mu \mathrm{g} / \mathrm{ml}$ & \\
\hline \multirow[t]{2}{*}{7.} & \multirow[t]{2}{*}{ HAMF } & \multirow[t]{2}{*}{$>1000$} & \multirow[t]{2}{*}{$1 \mu \mathrm{g}$ LPS } & $500 \mu \mathrm{g} / \mathrm{ml}$ & \multirow[t]{2}{*}{ Aqueous } \\
\hline & & & & $250 \mu \mathrm{g} / \mathrm{ml}$ & \\
\hline 8. & LPS Control & $1 \mu \mathrm{g}$ & LPS & $1 \mu \mathrm{g}$ & - \\
\hline 9. & Dexamethasone & $100 \mu \mathrm{M}$ & $1 \mu \mathrm{g} \mathrm{LPS}$ & $100 \mu \mathrm{M}$ & - \\
\hline
\end{tabular}


RASĀYAN J. Chem.

Vol. 14 | No. 1 |212-220| January - March | 2021

\section{IL-6 ELISA Study}

Table-3: Quantitative Determination of IL-6 for the Samples treated with THP-1 Cells

\begin{tabular}{|c|c|c|c|}
\hline S. No. & Name of the Sample & Concentration Tested $(\mu \mathrm{g} / \mathrm{ml})$ & \%IL-6 Inhibition \\
\hline \multirow[b]{2}{*}{1.} & \multirow{2}{*}{$\mathrm{CO}$} & 200 & 86.36 \\
\hline & & 100 & 79.03 \\
\hline \multirow[b]{2}{*}{2.} & \multirow{2}{*}{$\mathrm{COHF}$} & 200 & 85.87 \\
\hline & & 100 & 62.92 \\
\hline \multirow{2}{*}{3.} & \multirow{2}{*}{ COMF } & 100 & 86.23 \\
\hline & & 50 & 84.47 \\
\hline \multirow[b]{2}{*}{4.} & \multirow[b]{2}{*}{ BPS } & 500 & 82.63 \\
\hline & & 250 & 29.66 \\
\hline \multirow{2}{*}{5.} & \multirow{2}{*}{ HMEP } & 200 & 82.54 \\
\hline & & 100 & 83.21 \\
\hline \multirow{2}{*}{6.} & \multirow{2}{*}{ HMAP } & 500 & 79.16 \\
\hline & & 250 & 58.69 \\
\hline \multirow[b]{2}{*}{7.} & \multirow[b]{2}{*}{ HAMF } & 500 & 52.30 \\
\hline & & 250 & 39.96 \\
\hline 8. & LPS & $1 \mu \mathrm{g}$ & 0.00 \\
\hline 9. & Dexamethasone & $100 \mu \mathrm{M}$ & 77.05 \\
\hline
\end{tabular}

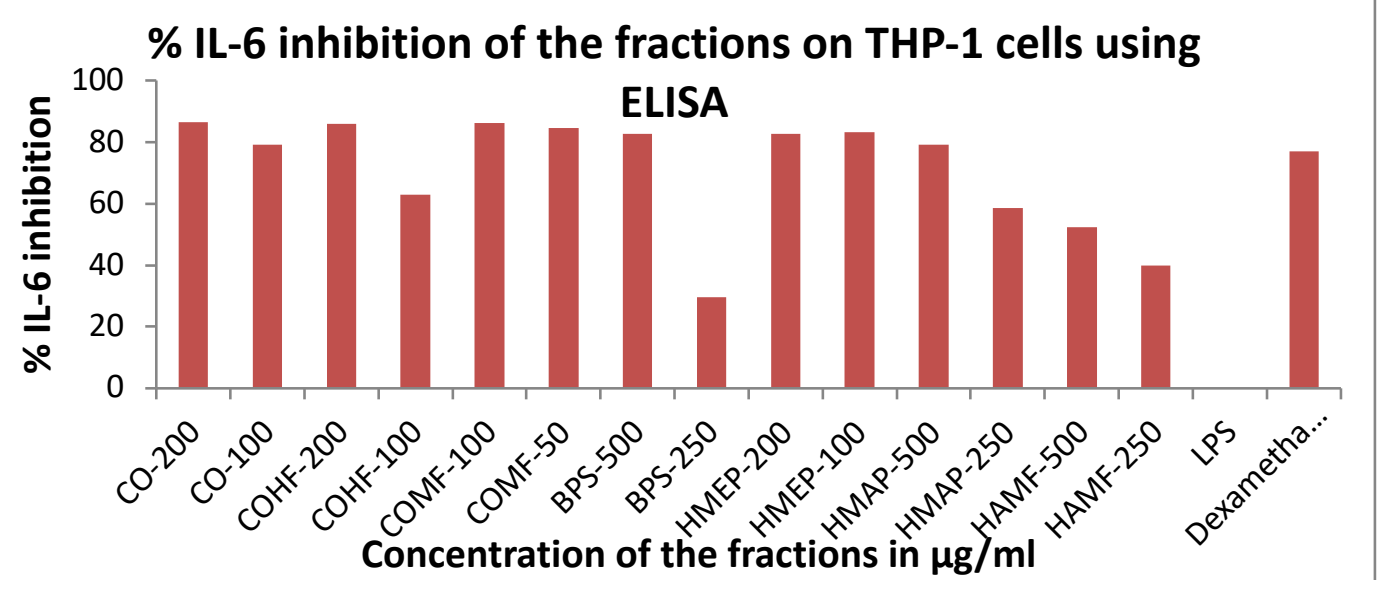

Fig.-1: Effect of Fractions on LPS $(1 \mu \mathrm{g} / \mathrm{ml})$ induced IL-6 production from THP-1 Cells.

\section{TNF-œ ELISA Study}

Table-4: Quantitative Determination of TNF-œ for the Samples treated with THP-1 Cells

\begin{tabular}{|c|c|c|c|}
\hline S. No. & Name of the Sample & Concentration Tested $(\mu \mathrm{g} / \mathrm{ml})$ & $\begin{array}{c}\text { \%TNF } \\
\text { Inhibition }\end{array}$ \\
\hline \multirow[b]{2}{*}{1.} & \multirow{2}{*}{$\mathrm{CO}$} & 200 & 24.43 \\
\hline & & 100 & 6.45 \\
\hline \multirow{2}{*}{2.} & \multirow{2}{*}{$\mathrm{COHF}$} & 200 & 0.00 \\
\hline & & 100 & 0.00 \\
\hline \multirow{2}{*}{3.} & \multirow{2}{*}{ COMF } & 100 & 87.09 \\
\hline & & 50 & 40.99 \\
\hline \multirow{2}{*}{4.} & \multirow{2}{*}{ BPS } & 500 & 0.00 \\
\hline & & 250 & 0.00 \\
\hline \multirow{2}{*}{5.} & \multirow{2}{*}{ HMEP } & 200 & 89.88 \\
\hline & & 100 & 0.00 \\
\hline \multirow{2}{*}{6.} & \multirow{2}{*}{ HMAP } & 500 & 0.00 \\
\hline & & 250 & 0.00 \\
\hline \multirow{2}{*}{7.} & \multirow{2}{*}{ HAMF } & 500 & 0.00 \\
\hline & & 250 & 0.00 \\
\hline 8. & LPS & $1 \mu \mathrm{g}$ & 0.00 \\
\hline 9. & Dexamethasone & $100 \mu \mathrm{M}$ & 71.17 \\
\hline
\end{tabular}




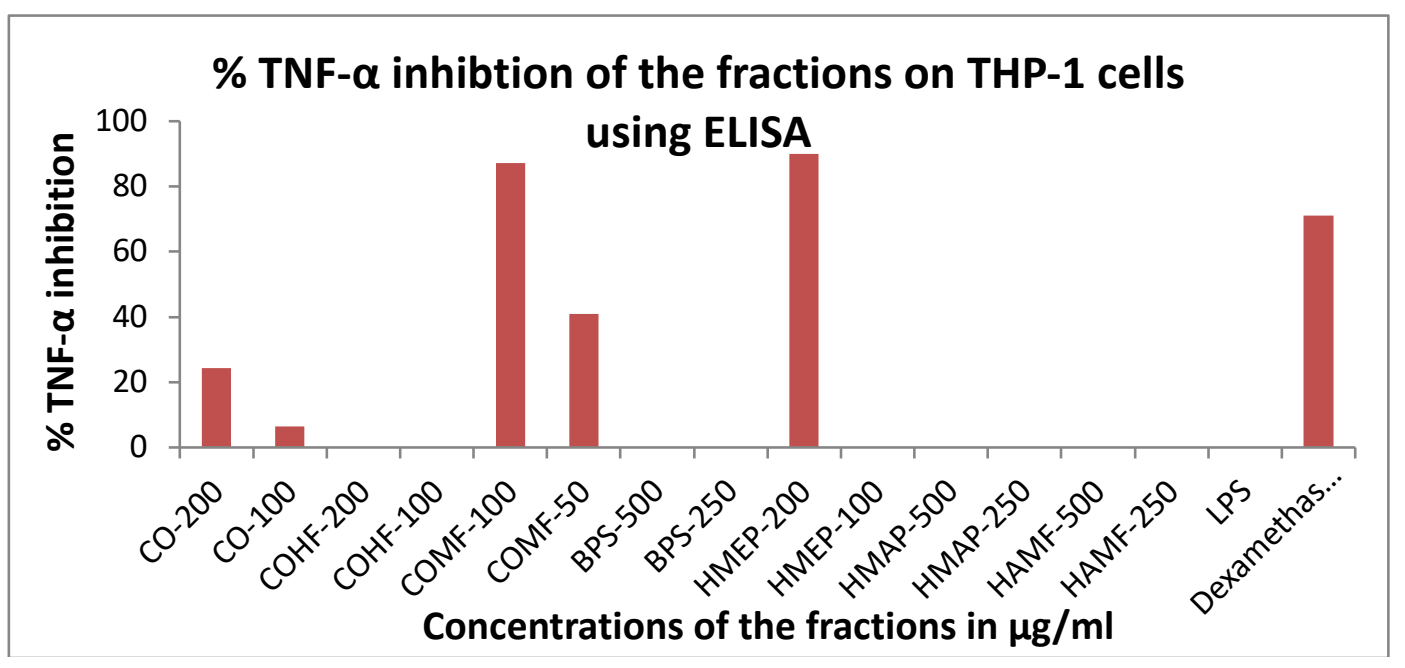

Fig.-2: Effect of Fractions on LPS $(1 \mu \mathrm{g} / \mathrm{ml})$ induced TNF-œ production from THP-1 Cells

The \% IL-6 inhibition of the fractions obtained were COHF- 85.87 and 62.92, COMF- 86.23 and 84.47, HMEP- 82.54 and 83.21, HAMF- 52.30 and 39.96 and HMAP- 79.16 and 58.69, CO- 86.36 and 79.03 and BPS- 82.63 and 29.66 respectively. Three fractions showed good inhibition of TNF-œ; the \% TNF- $\propto$ inhibition of the fractions obtained were COMF- 87.09 and 40.99, HMEP- 89.88 and 0.00 and $\mathrm{CO}-24.43$ and 6.45 respectively.

\section{HPTLC Estimation of CO, COHF and COMF}

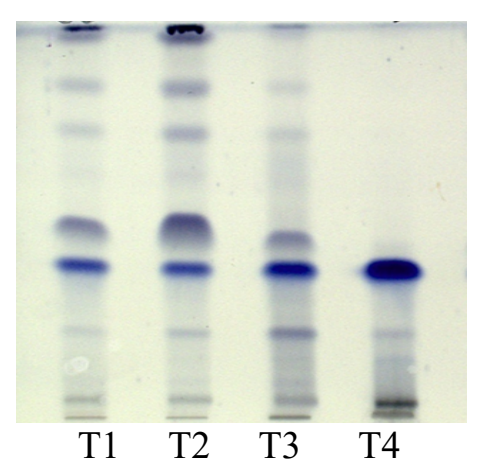

Track IDs $: \mathrm{T} 1=\mathrm{CO}, \mathrm{T} 2=\mathrm{COHF}, \mathrm{T} 3=\mathrm{COHP}, \mathrm{T} 4=\mathrm{COMF}$

Fig.-3: HPTLC Profile of CO, COHF and COMF

The HPTLC profile showed the presence of capsaicinoids (indicated by blue color) after derivatization with vanillin sulphuric acid reagent.

\section{HPTLC Estimation of BPS}

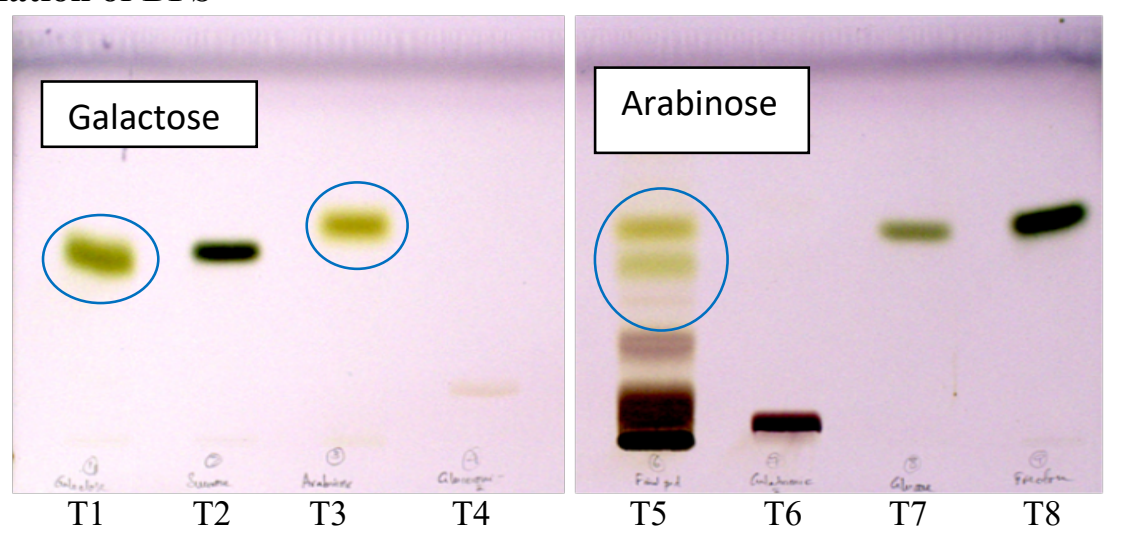

$\mathrm{T} 1=$ Galactose, $\mathrm{T} 2=$ Sucrose, $\mathrm{T} 3=$ Arabinose, $\mathrm{T} 4=$ Glucoronic acid, $\mathrm{T} 5=$ Crude polysaccharide $($ After hydrolysis), $\mathrm{T} 6=$ Galacturonic acid, $\mathrm{T} 7=$ Glucose, $\mathrm{T} 8=$ Fructose

Fig.-4: HPTLC Profile of BPS 
The profile showed the presence of galactose and arabinose (identified by the colour band) in the water extract after derivatization with vanillin sulphuric acid reagent by comparing with the carbohydrate standards taken.

\section{HPTLC Estimation of HMEP}

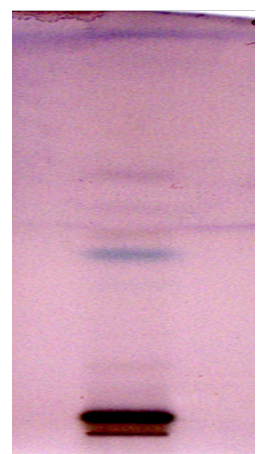

$\beta$-sitosterol

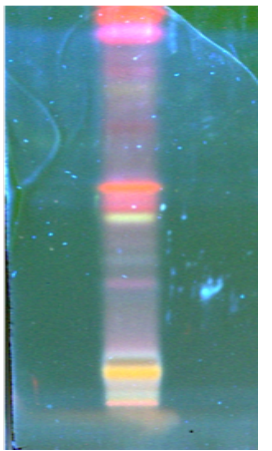

Luteolin

Fig.-5: HPTLC Profile of HMEP

The HPTLC profile showed the presence of three phytoconstituents ( $\beta$-sitosterol, Luteolin and a class of unknown terpenoid) in HMEP.

\section{LCMS Estimation of COMF, HMEP and BPS}

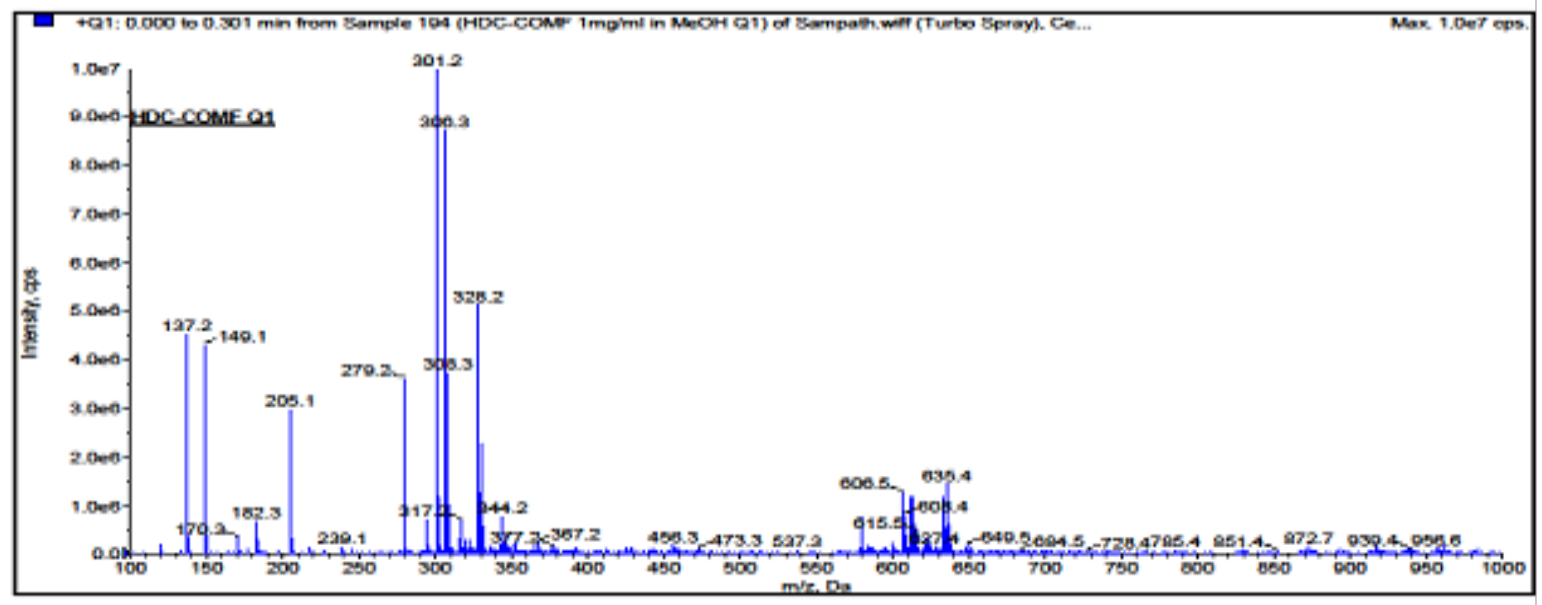

Fig.-6: LCMS Profile of COMF

The profile showed that protonated molecular ion gave the peak at $\mathrm{m} / \mathrm{z} 306.3$. It proved the presence of capsaicin.

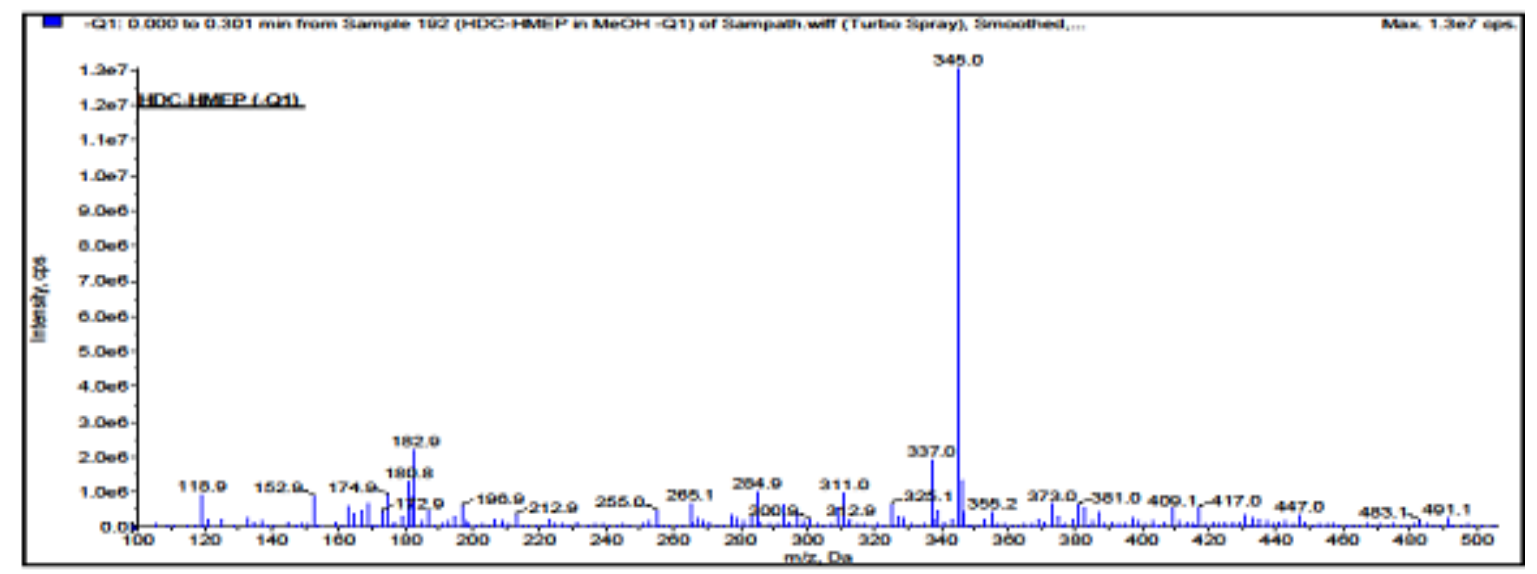

Fig.-7: LCMS Profile of HMEP 
The profile showed that protonated molecular ions gave the peak at $\mathrm{m} / \mathrm{z} 345.0,284.9$. It proved the presence of two flavonoid group of compounds, they are luteolin and lalioside.

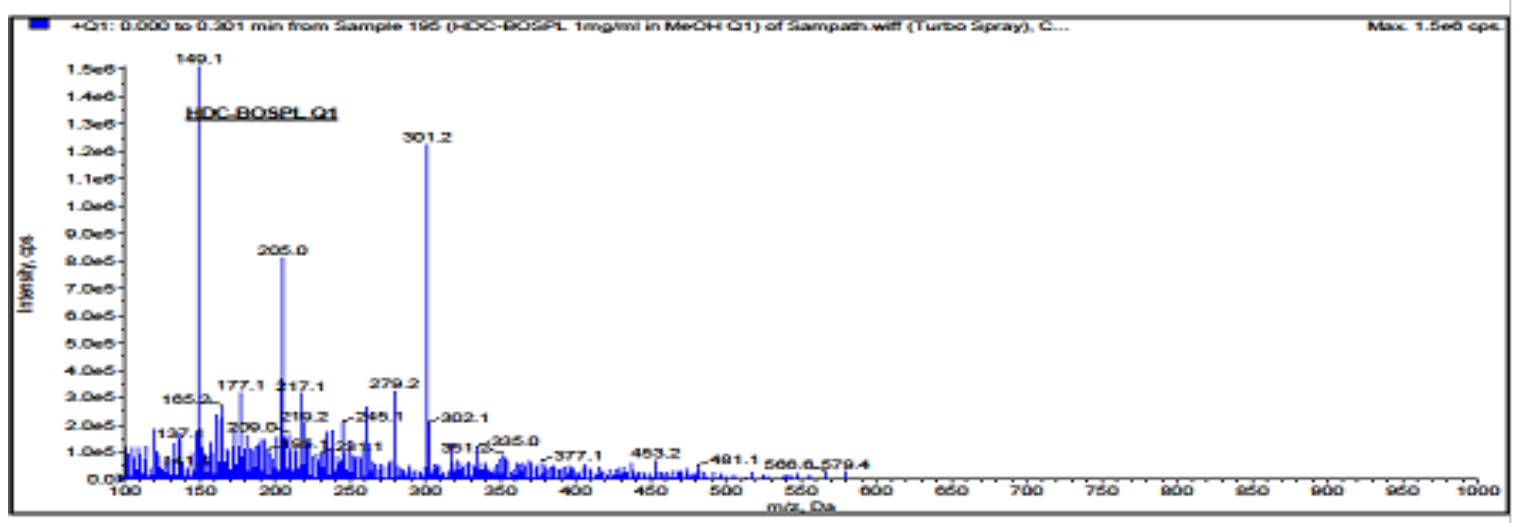

Fig.-8: LCMS Profile of BPS

The profile showed that protonated molecular ion gave the peak at $\mathrm{m} / \mathrm{z} 149.0$. It proved the presence of arabinose.

\section{CONCLUSION}

From the current research, it was observed that five fractions (CO, COHF, COMF, BOSPL and HMEP) showed good anti inflammatory activity. This activity was shown may be due to the presence of phytoconstituents which are identified by phytochemical analysis. So, these fractions may be used to prepare antiarthritic herbal formulations in the future. However, the in-vivo and clinical studies have to be carried out for further research.

\section{ACKNOWLEDGMENT}

The authors are grateful to Manipal College of Pharmaceutical Sciences, Manipal Academy of Higher Education, Manipal ,Karnataka and The Himalaya Drug Company, Karnataka for providing all infrastructure facility and support for carryout this work.

\section{REFERENCES}

1. R.S. Cotran, V. Kumar and T. Collins, Robbins Pathologic Basis of Disease, W.B. Saunders Company, Philadelphia, (1999).

2. K.E. Barbour, C.G. Helmick, M.A. Boring and T.J. Brady, Morbidity and Mortality Weekly Report, 66, 246(2017), DOI:10.15585/mmwr.mm6609e1

3. S.Y. Ranade and S. Ram, International Journal of Pharmaceutical Sciences and Research, 4(10), 3782(2013), DOI:10.13040/IJPSR.0975-8232.4(10).3782-94

4. A. S. Fauci, E. Braunwald, D. L. Kasper, S. L. Hauser, D. L. Longo and J. L. Jameson, Harrison's Principle of Internal Medicine, Mc-Graw Hill Companies, New York, United States of America, (2005).

5. C. Chunxia, Z. Peng, P. Huifang, R. Hanli, H. Zehua and W. Jizhou, Journal of Ethnopharmacology, 133, 573(2011), DOI:10.1016/j.jep.2010.10.035

6. S. H. Venkatesha, B. Astry, S. M. Nanjundaiah, Hong R. Kim, R. Rajaiah and Y. Yang, Asian Journal of Pharmaceutical Sciences, 11(2), 301(2016), DOI:10.1016/j.ajps.2016.02.003

7. M. Choudhary, V. Kumar, H. Malhotra and S. Singh, Journal of Intercultural Ethnopharmacology, 4, 147(2015), DOI:10.5455/jice.20150313021918

8. D.J. Bennett and G.W. Kirby, Journal of the Chemical Society C: Organic, 442, 446 (1968), DOI: $10.1039 / j 39680000442$

9. R. Jin, J. Pan, H. Xie, B. Zhou and X. Xia, Chromatographia, 70(5-6), 1011(2009), DOI: $10.1365 / \mathrm{s} 10337-009-1248-\mathrm{Z}$

10.J.P. Wang, M.F. Hsu and C.M. Teng, Thrombosis Research, 36(6), 497(1984), DOI: 10.1016/0049-3848(84)90189-0

11.H. Wang, C. Zhang, Y. Wu, Y. Ai, D.Y. Lee and R. Dai, Biomedical Chromatography, 28, 1402, 1408 (2014), DOI:10.1002/bmc.3182

12.B.A. Shah, G.N. Qazi and S.C. Taneja, Natural Product Reports, 26(1), 72(2009), DOI: $10.1039 / \mathrm{b} 809437 \mathrm{n}$ 
13.C.K. Kokate, A. P. Purohit and S. B. Gokhale, 2013, Terpenoids, in: Pharmacognosy, Nirali Prakashan, Pune, India, pp. 14.113

14.S. Dwivedi, D. Gupta and K.K. Sharma, Journal of Medicinal and Aromatic Plant Sciences, 22, 616(2000)

15.D. Kirkland and D. Marzin, Mutation Research, 537(2), 183(2003), DOI:10.1016/s13835718(03)00077-9

16. Sukh Dev, A Selection of Prime Ayurvedic Plant Drugs, Ancient- Modern Concordance, Anamaya Publishers, New Delhi, p. 276, 279 (2006).

17.S. Gupta, M. Ali, K.K. Pillai and M.S. Alam, Fitoterapia, 64, 365(1993)

18.B.H. Alia, A.K. Bashir and MOM Tanira, Pharmacology, 51, 356,(1995), DOI: $10.1159 / 000139347$

19.M. R. Sahoo, S. R. Varma, N.K. Patel, T. O. Sivaprakasam, A. Mishra and G. Muguli et al, Journal of Food Biochemistry, 41(3), 1(2017), DOI:10.1111/jfbc.12353

[RJC-5986/2020] 